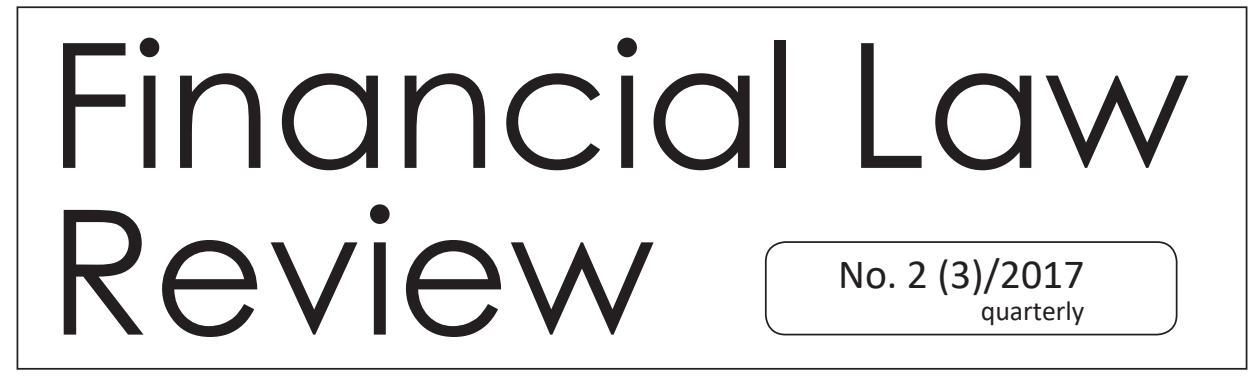

UNIVERSITY OF GDAŃSK • FACULTY OF LAW AND ADMINISTRATION

http://www.ejournals.eu • http://czasopisma.bg.ug.edu.pl

\title{
APEX ASSOCIATING BANK ${ }^{1}$
}

\author{
Rafat Mroczkozeski*
}

\begin{abstract}
The new legal framework of the functioning of cooperative banks in Poland ${ }^{2}$ opens wider possibilities for the cooperative banking sector regarding the choice of model of association. One of the potential strategies for banks, which do not perceive the institu-
\end{abstract}

\footnotetext{
${ }^{1}$ The article is a reprint of the article originally published in Finansowanie samorządu terytorialnego i jego zadań a Europejska Karta Samorządu Lokalnego. Local government financing and European Charter of Local Self-Government, J. Gliniecka, A. Drywa, E. Juchniewicz, T. Sowiński (red.), CeDeWu, Warszawa 2016

* Assistant Professor in the Department of Financial Law, Faculty of Law and Administration, University of Gdańsk

2 Introduced by the Act of 25 June 2015 amending the act on the functioning of the cooperative banks, their associations, and associating banks, and some relating acts (Journal of Laws of 2015, Item 1166). The activity of the cooperative banks in Poland is regulated by the general provisions (concerning credit institutions) and sectoral legislation i.e. the act of 7 December 2000 on the functioning of cooperative banks, their associations and associating banks (AFCB) (Uniform text, Journal of Laws of 2015, Item 2170).
} 
tional protection scheme ${ }^{3}$, created in the existing associations ${ }^{4}$ as an optimal solution, and which at the same time do not fulfil the requirements for conducting independent activity $^{5}$, is to establish a new associating bank and organize around it an association based on a deeper integration, but without the mutual guaranties of its participants in the scope of ensuring liquidity and solvency. The proposed solution applies both to the cooperative bank - through modelling its design on the basis of an apex bank, as well as the association - designed with the application of the integrated association model ${ }^{6}$. The main aim of this article is to present the theoretical model of the apex associating bank which may find application in the designing of association ${ }^{7}$, integrated association, as well as the institutional protection scheme.

The conducted analyses are to be used as verification of the hypothesis that the described model of apex bank shall:

1) provide cooperative banks with all the benefits associated with the activity within the framework of the association structure, and at the same time

2) enable the significant reduction of risk in the activity of the associating bank, and in consequence the risk of incurring by the cooperative banks the costs of materialization of risk generated by apex bank and

3) may contribute to the reduction of costs of functioning of the associating bank, and as a result also - the costs of services provided by that bank in favour of associated cooperative banks.

Organizing the association of cooperative banks around apex bank, may contribute also to the release of part of the financial resources of cooperative banks, involved so far with their capital in the associating banks, which conduct commercial activity, as well as within the framework of liquidity support for those banks. Subsequently, the increase of involve-

\footnotetext{
3 The institutional protection scheme within the meaning of Article 2(6) AFCB, established on the basis of the Article 113 (7) of the Regulation of the European Parliament and the (EU) Council No. 575/2013 of 26 June of 2013 r. on prudential requirements for credit institutions and investment firms and amending Regulation (EU) No. 648/2012, (Official Journal of EU L 176 of 27 June 2013) and the provisions of chapter III A of the act on functioning of cooperative banks, their associations, and associating banks.

4 The Association of Bank Polskiej Spółdzielczości and Association of SGB -Bank.

${ }^{5}$ Independent cooperative banks, are the banks which within the meaning of Article 1 (2) of AFCB, have initial capital at the level equivalent to at least EUR 5,000,000 and at the same time operate outside the structure of association or institutional protection scheme, or integrated association.

${ }^{6}$ Integrated association within the meaning of Article 2 section $7 \mathrm{AFCB}$ - is a formula of deeper cooperation between cooperative banks under agreement specifying at least: 1) the method of creating and functioning of aid system ensuring liquidity (liquidity support mechanism) and solvency (solvency support system) of the participants of association, 2) the principles of control and monitoring of the economic and financial situation of the participants of association, the compliance of their activity with the legal acts, association agreement provisions and participants' statuses, created, managed and supervised on the basis of provisions of Chapter III b of the act on the functioning of cooperative banks, their associations, and associating banks.

7 Within the meaning of Article 2(3) AFCB.
} 
ment of the network of cooperative banks organized in such a way in the crediting action in the traditional areas of activity of those banks can be expected, among others, in the local government sector. Because the locally operating cooperative banks ${ }^{8}$ are a natural source of financing for the entities of the local government and related entities of the public finance sector and local government companies. The organizational and legal solutions propounded in this article, meeting the expectations of cooperative banks, may also indirectly contribute to the increase of availability of financing provided by those banks to local governments and their entities through such instruments as loans or municipal bonds. Consequently, they may be regarded as beneficial from the point of view of practical implementation of the principle of providing the local communities with the access to domestic capital market expressed in Article 9 (8) of the European Charter of Local Self-Government ${ }^{9}$.

The implementation of the research goal adopted in this study requires the application of legal methods, such as in particular the general theoretical method and the formal-dogmatic method.

\section{Key words:}

apex associating bank, cooperative banks, European Charter of Local Self-Government

\section{Genesis of the apex associating bank}

The associating banks currently operating in Poland combine two functions: apex and commercial. Despite the fact that they had been primarily established to provide associating services in favour of cooperative banks, from the beginning they have been also providing banking services for the non-financial clients. The developed commercial activity of the associated banks has been absorbing their capital and human resources, at the expense of their apex activity. From the perspective of ownership, this activity has proved to be capital-absorbing, risky and economically ineffective. In consequence the cooperative banks ${ }^{10}$ as shareholders and at the same time recipients of the services bear the costs related to the functioning of associating banks and using their services, disproportionately to the benefits achieved in this respect.

\footnotetext{
${ }^{8}$ More information on the cooperative bank as local bank - A. Zalcewicz, Bank Lokalny. Studium Prawne., Warsaw 2013.

9 Drawn up in Strasbourg on 15 October 1985, ratified by the Republic of Poland (Journal of Laws of 1994, No. 124, item 607, as corrected).

${ }_{10}$ More details - A. Zalcewicz, Bank Spółdzielczy. Aspekty prawne tworzenia i funkcjonowania, Warszawa 2009.
} 
The described above, two-functional operational model of associating banks, in combination with the structural excessive liquidity of cooperative banks absorbed at the level of association, induces pressure on the increasing of credit activity of the associating banks. The presented mechanism, taking into consideration the weak corporate governance, executed by a dispersed stakeholders structure, consisting mainly of cooperative banks, leads to the occurrence of moral hazard on the side of the people managing the associating bank. At the same time, there is an objective difficulty in obtaining the adequate managerial staff combining the experience in the managing of commercial bank with the knowledge of the specifics of cooperative sector. The above factors manifest themselves cyclically with a low, against the background of commercial banks' sector, quality of the credit portfolio of associating banks, resulting in the necessity to set up provisions, reconstruct the business and recapitalize, etc.

At the same time, apart from the above factors, underlying the structural weakness of the cooperative sector and generating systemic risk, the legislator and supervisor have decided to adopt a new model for the existing associations - the institutional protection scheme, which not only does not solve the above problems but also consolidates them, generating at the same time new costs and risks for the cooperative banks.

The answer to the above negative phenomena, occurring with varying intensity in both of the associating banks in Poland, as well as being the result of the decision to establish institutional protection schemes in both associations, is the concept described in this publication of establishing of a new integrated association with the associating bank organized as an apex bank. It has become feasible due to the latest amendment to the act on functioning of cooperative banks, their associations and associating banks, which has introduced a new definition of an associating bank. In compliance with the latest wording of Article 2(2) AFCB. "associating bank" - shall mean a bank in the form of a joint stock company, established by cooperative banks, if the bank associates at least one cooperative bank under the terms of Article 16 AFCB and has initial capital of at least four times the amount specified in Article 32 (1) of the Act - Banking Law. The removal from the definition of the enumerative catalogue of banks referenced by their name, in combination with the furnishing of the definition with a new wording, based on the substantial premises in place of subjective ones, was decisive in creating the possibility to establish new associating banks. 
The admissibility of founding the association on the model of apex associating bank was confirmed by the Financial Supervision Authority. In the sectoral document of 2013 the Office of the Polish Financial Supervision Authority (OPFSA) expressed the opinion that the associating organization based on a different model than the institutional protection scheme is possible. At the same time, it points out that this will require changes in relation to the current financial and organizational models of associations, involving first of all the total or partial resignation of associating banks from the high risk commercial activities. The implementation of this concept - in accordance with the OPFSA position, shall require the solving of the problem of covering the costs of functioning of apex bank, and therefore the solution to the issue, repeatedly raised by the supervision (and never settled in a satisfactory way), of the calculation and full coverage of the costs provided in favour of associated cooperative banks by the associating banks. At the same time, it is one of the three requirements indicated by the Financial Supervision Authority for the integrated association. ${ }^{11}$.

\section{The essence of the apex associating bank}

The apex associating bank in the concept of the author is a special type of bank defined in Article (2)(2) AFCB. In compliance with the new statutory definition the associating bank is a bank in the form of a joint stock company, established by cooperative banks, if the bank associates at least one cooperative bank under the terms specified in Article 16 AFCB and has initial capital of at least four times the amount specified in Article 32 (1) of the act - Banking Law i.e. the equivalent of 20 million Euro. This definition does not mention by name the catalogue of associating banks, and instead introduces the subjective and objective criteria, leading to the acknowledgement of the bank in the form of a joint stock company as an associating bank. Although the modification of the analysed definition introduced by the act of 25 June 2015 on the amendment of the Act on functioning of cooperative banks, their associations and associating banks, and some relating Acts ${ }^{12}$, fulfils the postulates of opening the catalogue of banks which can perform the associating functions raised in the doctrine ${ }^{13}$, however, it should still

\footnotetext{
11 UKNF [OPFSA], Analiza sytuacji bankowego sektora spółdzielczego, w tym funduszy własnych, w 2012 r. oraz informacja o przebiegu prac nad możliwymi modelami działania zrzeszeń $w$ kontekście Dyrektywy CRD IV oraz Rozporzadzenia CRR, Warsaw 2013, pp. 20-21.

12 Journal of Laws of 2015, Item 1166.

${ }_{13}$ In relation to the previous wording of the associating bank definition, it has been raised in literature that it should only define the criteria that the bank should fulfil, in order to be considered an associating bank, and not list the associating banks by name. It has been postulated that
} 
be considered imperfect. Since it omits the key feature of the associating bank, which is providing cooperative banks with the associating services, the specific catalogue of which was determined in Article 19 (20) AFCB. Analysing the scope of activities of an associating bank indicated in Article 19 (1) and (2) AFCB, two main functions of the associating bank may be identified: apex (service activity in favour of associated cooperative banks - Article 19 (2) AFCB) and commercial (providing banking services in favour of an unlimited number of clients - Article 19 (1) AFCB).

The main feature of the associating apex bank, which distinguishes it from the existing associating banks is the focus on the execution of only one function - service activity in favour of the cooperative banks (apex function). Within its framework, it plays in the association for those banks the same role as the central bank in the financial system for the commercial banks, thus it manages liquidity and is the lender of the latter institution.

The associating apex bank is a bank the scope of activity of which is limited to the activities in favour of cooperative banks indicated in Article 19 (2) AFCB and other activities specified in the Act - Banking Law or in other acts, in the scope in which they are necessary to ensure the proper performance of associating services. Within the scope of activity of this bank, in particular the activities relating to the collecting of deposits and granting loans in favour of cooperative banks in order to regulate their financial liquidity, are included.

The apex associating bank should perform banking activities exclusively in favour of: cooperative banks associated with it and independent cooperative banks, which have concluded with it a framework cooperation agreement or an agreement for providing particular services. At the same time, the bank does not perform banking activities for non-financial entities, in particular: does not collect deposits from them, does not grant them loans and credits, does not perform other settlement activities in their favour, does not have a network of branches.

From such a perspective the mission of the apex associating bank is providing cooperative banks with associating services at the highest level in order to increase

\footnotetext{
possessing by cooperative banks in a bank in the form of a joint stock company, applying for the status of an associating bank, a specified number of votes at the general meeting of shareholders, should be considered to be such a criterion - compare R. Wenerski, Uwagi do projektu ustawy o funkcjonowaniu banków spółdzielczych, ich zrzeszaniu się, bankach zrzeszających oraz o zmianie niektórych ustaw (in:) L. Pawłowicz, E. Gostomski (ed.), Wizja spółdzielczego sektora bankowego w Polsce, Zeszyty IBnGR 1999 No 25, p. 78.
} 
their level of competitiveness and ensure their advantage on the market of banking services, and also ensure their stable and secure functioning. Thus defined, the mission highlights a few characteristic features of the new type of associating bank, creating the new dimension of associating services:

- activity focused on providing services to cooperative banks,

- non-profit purpose of the activity,

- low cost model of activity,

- low level of business risk,

- supporting the stability and security of the activity of cooperative banks.

The apex associating bank's activity is characterized by being focused on providing services to cooperative banks. This means concentrating on the needs of cooperative banks, which translates into high quality of associating services and striving to continuously improve their quality. Another aspect is the resignation of the associating bank from the competitive activity with regard to cooperative banks. Although, in the existing associations such a ban is formally present, however, the analysis of the network of branches of associating banks and the cooperative banks associated with them leads to the conclusion that in many cases they carry out the same type of activity in the same area, which is providing banking services dedicated to the same group of clients. In practice, the discussed ban on competitive activity is not observed. With the assumption of resignation from commercial activity by the associating bank, the competitive activity with regard to cooperative banks could not be carried out by that bank.

Another feature of the apex bank is the essentially non-profit purpose of the bank's activity. Such a bank would carry out activity without the focus on the maximization of the profit. In consequence the distribution of income in the form of dividends could be abandoned, at the same time allocating the income from investments for the covering of costs of providing the mandatory associating services. Assuming the financing of other costs of those services would come from the fees contributed by cooperative banks, there would be no significant risk of balance loss, and therefore the necessity to cover it from the bank's capital. As a result, the necessity to continuously recapitalize the associating bank by the cooperative banks would cease. The capital needs of this bank should be fully and permanently satisfied by the one-time contribution of capital when establishing the joint stock company.

The flattened organizational structure, low employment rate and outsourcing services would allow for significant reduction of costs of the activity and providing 
associating services, in comparison to the ones incurred by the so far operating associating banks. The costs of providing obligatory associating services may be partially covered from the income from the investing of capital in safe financial instruments, and in the remaining part from the fees contributed by the cooperative banks. Such a model of co-financing of those costs allows for offering to cooperative banks the services at a price below their actual production cost. This formula allows to assume with high probability that those services will be the cheapest on the market.

Against the background of experiences resulting from the activity of the existing associations, the exceptional feature of the apex bank is the possibility to reduce the risk, both directly in the activity of this bank, as well as in relation to cooperative banks, which are its shareholders. This is the result of: reduction of risk in the activity of apex bank, limited mainly to the risk of the held liquid assets, elimination of crediting risk, and also the mechanism of division of apex activity costs between the cooperative banks using the associating services, which limits the possibility of occurrence of balance loss. The risk for shareholders could be reduced in the absence of the necessity to cyclically recapitalize the associating bank by the cooperative banks, as well as by guaranteeing the solvency and liquidity of the associating bank. In combination with the liquidity and solvency support mechanisms, organized within the framework of the integrated association, this would lead to the significant improvement of the stability and security of the associated cooperative banks.

\section{Versatility of the apex associating bank}

The model of the apex associating bank may find application in the designing of association ${ }^{14}$, integrated association, as well as the institutional protection scheme ${ }^{15}$.

In accordance with the OPFSA position, the transformation of the associating banks into apex banks could have been used as a measure to ensure fulfilment of the prudential standards introduced by the CRR, in associations without

\footnotetext{
${ }^{14}$ More on associations - A. Zalcewicz, Zasady funkcjonowania zrzeszeń banków spółdzielczych w Polsce i ich wpływ na rozwój sektora banków spółdzielczych (wybrane zagadnienia). Roczniki Prawnicze 2010 No. 22, pp. 91-105.

${ }_{15}$ More on the subject - R. Mroczkowski, P. Cioban, Modele działalności banków spółdzielczych w Polsce in nowych ramach prawnych, Monitor Prawa Bankowego 2014 No. 09 (46), p. 52 and following
} 
transforming them into the institutional protection schemes ${ }^{16}$. Such view was also presented in the doctrine ${ }^{17}$. Despite, however, being shared by a large group of banks in the BPS association, eventually, due to a coincidence of internal and external circumstances, it was not realized in the association in which the institutional protection scheme was created on 31 December 2015. It happened mainly as a result of a decisive position of the supervisor who had indicated that the organizational transformation of the association into the institutional protection scheme involved less expenditures than business remodelling of the associating bank towards the apex bank ${ }^{18}$. Nevertheless, in the light of the above diagnosis of the situation of the cooperative banking sector, the solution based on the gradual reduction of the scope of commercial activity of the associating bank until the complete termination would be an adequate response to the problems which forced the BPS to implement the recovery programme.

Application of the design of the apex associating bank could contribute to simplification of the association organizational structure within the framework of the institutional protection scheme. There are two alternative institutional solutions in the IPS statutory organizational model in the scope of the system management. The protection scheme agreement may mandate the IPS management to the managing bank or a management unit established for this purpose in the form of a joint stock corporation or a legal person cooperative (Article 22d $\mathrm{AFCB})^{19}$. The first solution has obvious advantages associated with its higher cost efficiency. The bodies of the protection scheme which is managed by the associating bank are the bodies of the bank, i.e. general assembly of shareholders as an ownership entity and the Board of the bank, also functioning as a managing entity of the protection scheme. The supervising body of the IPS is the Association Council. Due to this the legislative, control and management functions arising from the statute of the associating bank, association agreements and protection scheme agreements are realized by the same bodies. The performance of dual-functions by these bodies - within the association structure and the parallel IPS structure leads to the reduction of establishing and functioning costs of the protection scheme. In this respect, such a model should be considered as more effective with regard to the costs than the IPS management model based on a management unit

\footnotetext{
${ }^{16}$ UKNF [OPFSA], Analiza sytuacji bankowego sektora spółdzielczego ..., pp. 20-21.

17 Cf. R. Mroczkowski, P. Cioban, Modele działalności banków spółdzielczych w Polsce ..., p. 52 and following

18 UKNF [OPFSA], Analiza sytuacji bankowego sektora spółdzielczego ..., pp. 20-21.

19 More on this subject: R. Mroczkowski, System ochrony instytucjonalnej. Szanse i zagrożenia dla banków spółdzielczych w Polsce, Monitor Prawa Bankowego 2015 No. 05 (54), p. 47 and following
} 
established for this purpose in the form of a joint stock corporation or a legal person cooperative. Simultaneously, the analysed model, according to the author, may be used only for establishing IPS within an association with an apex associating bank. Such a bank does not conduct commercial activity and invests its assets only in secure financial instruments. Therefore, such activity is identified as low risk. Provided the bank fulfils the condition, it may perform certain functions in relation to cooperative banks, such as: monitoring and classification of risk, as specified in Article 113(7) CRR and not performing simultaneously the dual role of the controlling and controlled entity (in relation to its own activity)

In respect of adoption of the institutional protection scheme model in the end of 2015 by both associations operating in Poland with simultaneous maintaining the dual-function character of the associating banks (commercial activity combined with apex activity), the theoretical model of the associating bank discussed in this study, in the current realities, may be carried out solely within a new integrated association. There is no doubt that in respect of the new definition of the associating bank specified in Article 2 (2) AFCB, there is a possibility of establishment of the associating bank which scope of activity will be concentrated around the associating services specified in the list in Article 19(2) $\mathrm{AFCB}$, i.e. the apex bank. Such limited activities of an associating bank could be particularly well realized within an integrated association. The apex bank focusing its activity on providing associating services for cooperative banks would be adapted to managing and would be the essence of the integrated association ${ }^{20}$, an aid system ensuring liquidity (liquidity support mechanism) and solvency (solvency support system) of the participants of association At the same time, within the framework of broadened competences in relation to Article 19 AFCB, the bank would conduct control and monitoring of the economic and financial situation of the participants of association, the compliance of their activity with the legal acts, association agreement provisions and participants' statutes.

\section{The scope of activity of apex associating bank}

The limitation of the scope of activity, both in subject and object terms, results from the apex character of the activity of associating bank.

Referring to the first of the aforementioned limitations (the subject one) it is appropriate to indicate that the apex associating bank performs banking activities exclusively in favour of: cooperative banks associated with it and independent

${ }^{20}$ Cf. Article 22o(2) and Article 22q - 22s AFCB. 
cooperative banks which have concluded with it a framework cooperation agreement or an agreement for providing particular services.

The subjective scope of tasks of the associating bank is specified in the current legal regulations, especially in Article 19(2) AFCB as well as the statute of the bank and the association agreement. Modelling the associating bank design on the apex model means focusing the activity on the associating services along with the simultaneous resignation of banking activities indicated in Article 19 AFCB in relation to the non-financial entities and financial institutions, except for the cooperative banks which have concluded with the associating bank an association agreement or a cooperation agreement for providing particular banking services.

Classification of the activities of the apex associating bank may be performed based on various criteria, including the legal character and functional criterion in particular.

The provision of services, which are obligatory according to the current law, for the cooperative banks which do not have the independent bank status is of key importance in the activity of an apex associating bank. Taking into account the foregoing, the activities of an apex bank could be classified in two categories: mandatory and optional activities.

Mandatory activities are the ones which are absolutely obligatory in terms of execution of them by the associating bank for the cooperative bank, what is specified in the legal regulations, especially Article 19(2) AFCB. Moreover, also the activities which indispensability in the light of the law result from the legal and financial construction of the association, as specified in the agreement.

The following list of activities is obligatory to the associating bank:

1. Administering the current bank accounts of cooperative banks, where the banks:

- maintain the minimum reserves and

- perform a financial settlement through them.

2. Maintaining the obligatory reserve of cooperative banks on an account in NBP (The National Bank of Poland).

3. Administering a separate account, on which the assets of the cooperative banks are deposited, covering the guaranteed deposit protection fund, within the system operated by the Banking Guarantee Fund . 
4. Fulfiling the reporting and informational obligations for the cooperative banks, in respect of the National Bank of Poland and the Banking Guarantee Fund.

5. Control of the the compliance of the cooperative banks activity with the provisions of the association agreement, legal acts and statutes.

Additionaly, due to the planned adoption of the structure of an integrated association, the associating bank should ensure the following services to the cooperative banks:

1. Managing the liquidity of the cooperative banks, including:

- collecting the mandatory deposits,

- granting loans:

- to support the current cash flow liquidity.

- for the accepting bank to support the process of merging of the banks,

- for other purposes indicated in the association agreement.

2. Supporting the solvency of cooperative banks, including:

- collecting and managing the aid fund,

- granting guarantees and other securities,

- granting loans:

- for support of the realization of the internal recovery program,

- for other purposes indicated in the association agreement.

The possibility to provide the additional activities by the associating bank which are not directly stipulated in the provisions of law, as specified in Article 19(2) (8) AFCB. The aforementioned article is the basis for provision of additional activities specified in the association agreement. The list of optional activities is inherently open. The only restriction arises from the essence of these activities which should have the form of services performed by the associating bank for the cooperative banks.

The basic motive for the outsourcing of chosen services by the cooperative banks for the associating bank is the effectiveness of its performance. Provided that these services may be obtained outside the cooperative bank structure in a cheaper and faster way, and on a higher level, such solution should be considered as more efficient. Should these services be provided by the associating bank, it requires covering full costs of realizing them. Simultaneously, it should be possible for the cooperative banks to contract these services on the free market with other suppliers.

The list of optional activities of the apex associating bank may include: 
1. Collecting deposits from cooperative banks exceeding the amounts resulting from the mandatory deposits.

2. Keeping the accounts of the soft loans interest relief.

3. Representation of the cooperative banks in the external relations in the matters arising from the association agreement, e.g. in relation to the National Bank of Poland, Financial Supervision Authority and Banking Guarantee Fund.

4. Internal inspection in the cooperative banks.

5. Mediation in making foreign exchange operations, including the mediation in money transfer operations and settlements of foreign exchange operations on behalf of the customers of cooperative banks.

6. Representation of the cooperative banks in issuing and servicing payment cards.

7. Designing and help in the implementation of the uniform accounting principles.

8. Assistance and legal advice in the following areas:

- preparation and sharing framework statutes, regulations and procedures in cooperative banks.

- preparation of other internal documents internally used by cooperative banks.

- informing of changes in the current legal situation and the obligations for cooperative banks resulting from it

- lobbing for the sector of cooperative banks,

- organising conferences, symposiums, training sessions and workshops,

9. Performing consulting activities in respect of:

- conducting marketing research,

- promotion and implementation of new banking products,

- implementation of modern banking technologies,

- development and ensuring compatibility of telecommunications and IT infrastructure.

10. Administering the financial intermediation for cooperative banks, e.g. in the form of deposit and loan exchange (a Internet banking window for affiliated cooperative banks)

11. Other activities indicated in the association agreement.

The division of the activities on mandatory and optional should be reflected also in the way of their financing. The activity of apex associating bank should not be geared towards maximizing the profit. It is based on the assumption of full 
coverage of costs in subsequent settlement periods by revenues and pursuing the profit on the level securing the capital against the loss of value due to inflation processes. At the same time, it is not assumed to distribute any financial surpluses between shareholders. Such solution requires rigorous cost policy and guarantee of operating costs coverage by the associated cooperative banks.

Basically, an apex associating bank should generate low operating costs. It results from the simplified organizational structure, limitation of the number of organizational units, relatively low level of employment, services outsourcing, establishment of a headquarters outside Warsaw, etc..

An apex associating bank does not conduct commercial activity, thus it is devoid of a possibility of financing the costs of associating services from the surplus incomes over the costs of commercial activity. In order to ensure the operating costs coverage of the bank, it is necessary to establish full charge for associating services. The operating costs of an apex associating bank should be financed from three main sources:

1) financial incomes, especially from the apex bank capital,

2) flat-rate contributions paid by the associated cooperative banks for mandatory associating services,

3) other fees paid by cooperative banks for optional associating services calculated based on actual costs (i.e. variable costs in their full amounts and participation in fixed costs).

Flat-rate contribution for mandatory service will be:

1) set for individual cooperative banks on the basis of transparent and objective criteria laid down in the association agreement,

2) covered by the associated cooperative banks in advance on a monthly basis during the financial year,

3) settled after the end of the financial year in the amount necessary to cover the full operating costs of the apex bank.

Adoption of functional criterion allows to single out five key operational areas of an apex associating bank for the benefit of cooperative banks ${ }^{21}$ :

1) accounting and reporting area

2) business support area

3) risk management support area

${ }^{21}$ Classification of operational areas of an apex associating bank and particular actions in these areas - cfollowing D. Bugajski, Presentation at the meeting of the cooperative banks representatives in Ilża, on 7 October 2015. 
4) organizational and legal support area

5) control and supervisory area

Figure 1. Scope of activity of apex associating bank

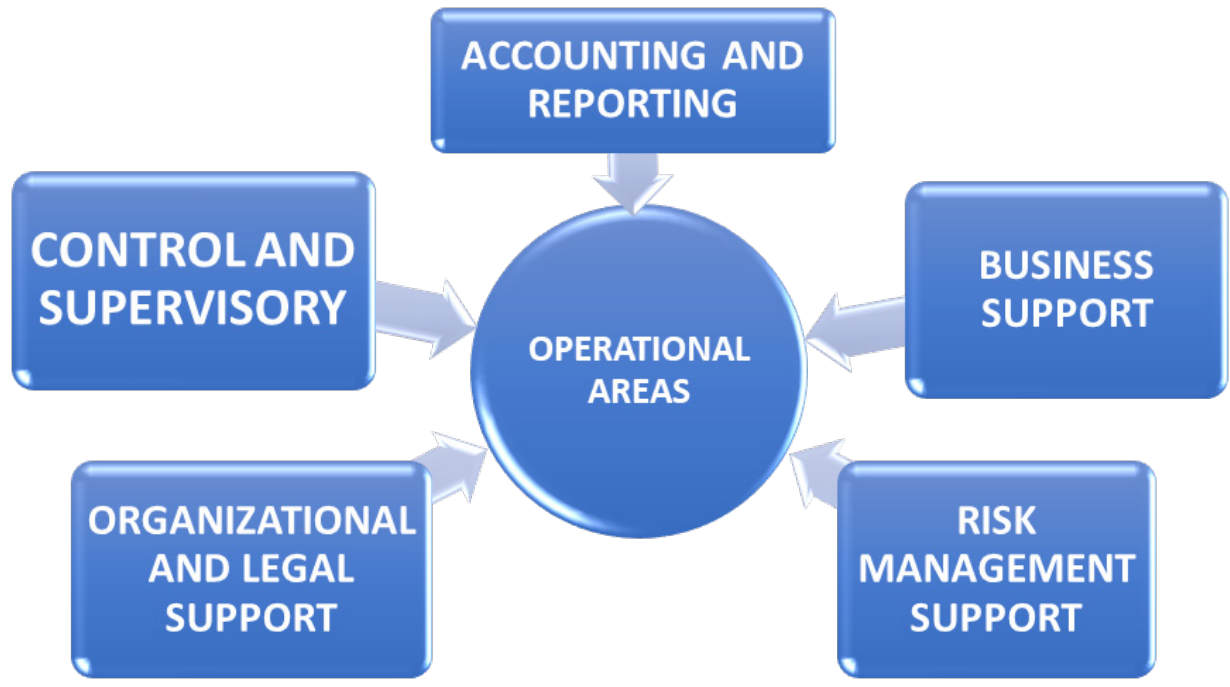

Source: D. Bugajski, Presentation at the meeting of the cooperative banks representativesin It $\dot{z}$, 7 October 2015.

Within the accounting and reporting area the following activities are realized:

1) administration of accounts and settlements of the associated banks: current accounts, mandatory reserve accounts, guaranteed deposit protection fund;

2) Obligatory reporting service (National Bank of Poland, Banking Guarantee Fund, Financial Supervision Authority, itd.);

3) accounting and reporting in respect of : soft loans (any), cards and other payment instruments, contributions and cash disbursement, settlements with the cooperating companies (WU, Credit Reference Agency, etc.);

4) preparation (in collaboration with technological partners of the association) of an offer of ICT solutions for settlement processes service in cooperative banks.

Within the business support area the associating bank may offer cooperative banks:

1) building a common image of the association;

2) preparation of a framework product offer for associated bank;

3) preparation of framework product regulations; 
4) creation and coordination of association marketing and promotion policies;

5) creation and coordination of cooperation of associated cooperative banks in terms of credit consortia;

6) preparation (in collaboration with technological partners of the association) of an offer of IT solutions for business processes service in cooperative banks.

The risk management support area includes such processes as:

1) designing framework regulations on risk management;

2) supporting the associated cooperative banks in fulfilling the supervisory standards, especially with regard to the liquidity risk;

3) preparation (in collaboration with technological partners of the association) of an offer of IT solutions for risk management processes service in cooperative banks.

The organizational and legal area includes such processes as:

1) designing framework regulations on: organization of the bank, security, personnel issues, tax issues, etc.;

2) ensuring (in collaboration with chosen partners of the association) legal service of the associated cooperative banks;

3) organizing and coordinating the conditions to satisfy the needs for training in the cooperative banks.

The Control and supervisory area includes such processes as:

1) control of the activity of the associated banks in the scope of compliance with the law and association agreement;

2) control of the observance of the supervisory standards by the cooperative banks;

3) providing the cooperative banks which do not have their own internal audit with service in this respect;

4) designing the framework regulations regarding internal control and audit;

5) representing the associated cooperative banks in the external relations in matters arising from the association agreement.

Classification of tasks of the apex associating bank within the particular areas should be reflected in its organizational structure and coincide with the sections functioning within the Cooperative Bank Service Department.

\section{Organizational structure of the apex associating bank}

The organizational structure of the apex associating bank should ensure: 
1) effective realization of basic tasks of the bank,

2) low costs of realization of the tasks,

3) compliance with the current law;

Realization of the fundamental aim of the apex associating bank which is the provision the cooperative banks with high quality associating services requires the creation of appropriate organizational structure. It is appropriate to single out all the organizational units related to the apex function of a bank to the Cooperative Bank Service Department, subjected to an appointed member of the Board. Such solution will allow for the efficient organization and management of the apex activity through entrusting the decisive power and responsibility to an appointed for this purpose member of the Board. Another feature of the structure is the relation of particular units within the Cooperative Bank Service Department with functionally singled out operating areas of the bank.

Furthermore, the next assumption associated with the organizational structure is the limitation of the departments to three and optimization of the number of organizational units in order to reduce the functioning costs of the apex associating bank. A consequence of adopting the apex model of activity is the lack of the organizational departments and units within the structure, related to the commercial operating activities.

The organizational structure of the apex associating bank should meet the requirements specified by the provisions of the law, including in particular: the Act of 29 August 1997 Banking Law $^{22}$ according to the wording in the Act of 5 August 2015 on macro-prudential supervision over the financial system and Crisis Management in the Financial System ${ }^{23}$, the Act of 7 December 2000 on functioning of cooperative banks, their associations and associating banks ${ }^{24}$, recommendations of the Financial Supervision Authority and rules of the corporate governance for supervised institutions.

\section{Conclusions}

Theoretical model of the apex associating bank presented in this study is an interesting alternative to the currently operating associating banks. It is a response to the contemporary problems of the cooperative banking sector in Poland which were best visible in the inclusion of the BPS S.A. in the recovery programme

${ }^{22}$ Uniform text, Journal of Laws of 2015, Item. 128, as amended

23 Journal of Laws of 2015, Item 1513

24 Uniform text, Journal of Laws of 2014, Item 109, as amended 
and the declaration of insolvency of the biggest bank in the association the Cooperative Crafts and Agriculture Bank in Wolomin. The reason of failure of both of these banks, the associating and the associated, were the aid, control and supervising mechanisms.

Simultaneously, the adopted solution in the context of the aforementioned situation, namely the implementation of the institutional protection scheme in the author's opinion - not only is not adequate in the light of the diagnosed condition, but also may contribute to the significant worsening of the financial stability of the cooperative banks which joined the IPS. Since they assumed the responsibility for the liquidity and solvency of all participants in the protection scheme for themselves, including the BPS S.A. which range of activity and costs of restructuring, being the derivative of the materialized risk, may occur disproportionate to the financial capacities of the remaining participants of the IPS.

According to the author, an adequate solution to the problems that occurred in the cooperative banking sector (with particular intensity in the BPS S.A. association) should be gradual termination of ineffective commercial activity and transformation of the association into its deeper formula - an integrated association.

An alternative solution for the cooperative banks which do not accept the risk related to joining the IPS is establishing an apex associating bank together with an integrated association around it. The analyses conducted by the author confirm the hypothesis stated in the introduction, that the apex bank may provide cooperative banks with full range of associating services at an optimal cost and reduced risk level of activity, thus with little probability that liquidity or capital support of the bank will ever occur necessary.

However, establishment of a new associating bank based on the apex model may encounter some difficulties related to the necessity of collecting registered capital which needs to be four time bigger that the one expected from a commercial bank $^{25}$. Taking into account the foregoing and considering the low operating risk of such bank, it is appropriate to postulate introduction of the statutory definition of the apex associating bank and resignation from additional requirements from it, as specified in Article 2 (2) AFCB. It would allow for establishing an apex bank with share capital at a level corresponding to the equivalent of at least 5 million Euro.

${ }^{25}$ Cfollowing Article 2 (2) AFCB in respect of Article 32(1) of the Act - Banking Law 


\section{List of abbreviations}

\section{Institutions}

IPS - The institutional protection scheme

FSA - Financial Supervision Authority

OPFSA - Office of the Polish Financial Supervision Authority

\section{Legislation}

ECLSG - European Charter of Local Self-Government drawn up in Strasbour on 15 October 1985, ratified by the Republic of Poland (Journal of Laws of 1994, No. 124, Item 607, as corrected).

CRR - regualtion of the European Parliament i UE Council No. 575/2013 of 26 June 2013 on prudential requirements for credit institutions and investment firms, amending Regulation (EU) No. 648/2012, (Official Journal of the EU L 176, of 27 June 2013)

AFCB - the Act of 7 December 2000 r. on functioning of cooperative banks, their associations and associating banks (Uniform text, Journal Of Laws of 2015, Item 2170).

\section{List of legal acts}

1. ECLSG - European Charter of Local Self-Government drawn up in Strasbourg on 15 October 1985, ratified by the Republic of Poland (Journal of Laws of 1994, No. 124 , Item 607 , as corrected).

2. CRR - regualtion of the European Parliament i EU Council No. 575/2013 of 26 June 2013 on prudential requirements for credit institutions and investment firms, amending Regulation (EU) No. 648/2012, (Official Journal of the EU L 176, of 27 June 2013).

3. the Act of 7 December 2000 on functioning of cooperative banks, their associations and associating banks (Uniform text, Journal of Laws of 2015, Item 2170).

4. the Act of 25 June 2015 amending the act on the functioning of the cooperative banks, their associations and associating banks, and some relating acts (Journal of Laws of 2015, Item 1166).

\section{Bibliography}

1. D. Bugajski, Presentation at the meeting of the cooperative banks representatives in Itzia, on 7 October 2015., not published.

2. Mroczkowski R., Cioban P., Modele działalności banków spółdzielczych w Polsce w nowych ramach prawnych, Monitor Prawa Bankowego 2014 No. 09 (46).

3. Mroczkowski R., System ochrony instytucjonalnej. Szanse i zagrożenia dla banków spółdzielczych w Polsce, Monitor Prawa Bankowego 2015 No. 05 (54).

4. PFSA, Analiza sytuacji bankowego sektora spółdzielczego, w tym funduszy własnych, w 2012 r. oraz informacja o przebiegu prac nad możliwymi modelami działania zrzeszeń w kontekście Dyrektywy CRD IV oraz Rozporządzenia CRR, Warsaw 2013. 
5. Wenerski R., Uwagi do projektu ustawy o funkcjonowaniu banków spółdzielczych, ich zrzeszaniu się, bankach zrzeszajacych oraz o zmianie niektórych ustaw (in:) L. Pawłowicz, E. Gostomski (ed.), Wizja spółdzielczego sektora bankowego w Polsce, Zeszyty IBnGR 1999 No 25.

6. Zalcewicz A., Bank lokalny. Studium prawne, Warsaw 2013.

7. Zalcewicz A., Bank Spółdzielczy. Aspekty prawne tworzenia i funkcjonowania, Warsaw 2009.

8. Zalcewicz A., Zasady funkcjonowania zrzeszeń banków spółdzielczych $w$ Polsce $i$ ich wpływ na rozwój sektora banków spółdzielczych (selected issues)), Roczniki Prawnicze 2010 No. 22. 